\title{
KÉSŐ KÖZÉPKORI KINCSLELET MOHÁCS-SÁRHÁTRÓL
}

\author{
NAGY BALÁZS* - GYÖNGYÖSSY MÁRTON** - GÁBOR OlIVÉR***
}

\begin{abstract}
2016 tavaszán Mohács-Sárháton egy késő középkori kincslelet került elő, mely összesen 61 dénárból, illetve egy ezüst fülesgombból áll. A kincslelet összetételében kivétel nélkül nova monetavereteket találunk, melyeket 1521 és 1525 között bocsátottak ki. Így a legkésőbbi veret alapján elrejtését, illetve földben maradását a törökök 1526. évi kivonulásával hozhatjuk összefüggésbe.
\end{abstract}

Kulcsszavak: kincslelet, nova moneta, mohácsi vész, törökök kivonulása

\begin{abstract}
A late medieval hoard of sixty-one denarii and a silver looped button came to light at MohácsSárhát in Spring 2016. The hoard is made up of nova moneta issues minted between 1521 and 1525. Thus, on the testimony of the latest issue, the burial of the hoard and the fact that it was not recovered can be associated with the withdrawal of the Turkish forces in 1526.
\end{abstract}

Keywords: hoard, nova moneta, Battle of Mohács, withdrawal of the Turkish forces

\section{Bevezetés}

2016 tavaszán Máté Tamás a Janus Pannonius Múzeum Régészeti Osztálynak ${ }^{1}$ és a Baranya Megyei Járási Hivatal Építésügyi és Örökségvédelmi Osztálynak ${ }^{2}$ jelentette, hogy ismert régészeti lelőhelyen kívül roncsolásmentes múszeres leletfelderítés módszerével öt késő középkori ezüstpénzt talált. A kutatás a fentiekben említett hivatalok szakembereinek jelenlétében folytatódott, ahol egy nap alatt további 30 ezüstpénz került elő. A felszín közeléből $(5-15 \mathrm{~cm})$ előkerült pénzek között több összetapadt is volt. Ez a tény,

Kézirat beérkezett: 2018. július 1.

*Nagy Balázs: Ferenczy Múzeumi Centrum. H-2000 Szentendre, Fő tér 2-5.; ELTE; BTK, TDI, A történelem segédtudományai doktori program, PhD-hallgató. H-1088 Budapest, Múzeum krt. 6-8.; e-mail: nagy.balazs@ muzeumicentrum.hu

**Gyöngyössy Márton: ELTE; BTK, Történelem Segédtudományai Tanszék, habilitált egyetemi docens. H-1088 Budapest, Múzeum krt. 6-8.; e-mail: kalnoki-gyongyossy. marton@btk.elte.hu

*** Gábor Olivér: Janus Pannonius Múzeum, H-7621 Pécs, Káptalan u. 5.; e-mail: gabor.oliver@jpm.hu

1 Érem-és kincsleletek kutatása Baranya megyében, kapcsolattartó: Gábor Olivér régész, Janus Pannonius Múzeum és Nagy Balázs, régész-numizmata, Ferenczy Múzeumi Centrum.

2 Kátainé Szajcsán Éva régész felügyelő, Pécsi Járási Hivatal Építésügyi és Örökségvédelmi Osztály. illetve a pénzek súrúsödése is többdarabos leletegyüttesre utalt. A lelőhely mezőgazdasági múvelésnek kitett terület, ami a pénzek vagy az egyéb fellelhetô régészeti tárgyak állapotát, épségét veszélyezteti. Mindezek tudatában indokoltnak láttuk a helyszín folyamatos roncsolásmentes kutatását, illetve mentőfeltárás megvalósítását. A 2016. évi őszi szántás után ismét roncsolásmentes múszeres leletfelderítést végeztünk, ami - ugyanott, ahol tavasszal - további ezüstpénzeket eredményezett. A mentőfeltárásra 2017 májusában került sor. ${ }^{3}$

\section{Módszer és leletanyag}

A lelőhely a Mohácsi-szigeten, Sárhát közigazgatási területén, a Karapancsai-fő́csatorna patkóalakban beszúkült részén található. A táj domborzati viszonyait tekintve sík, lapos terület, amelyet több egykori patakmeder tagol. A helyszínen több alkalommal végeztünk szisztematikus terepbejárással egybekötött múszeres leletfelderítést, ami a lelőhely szúkebb és tágabb vizs-

3 Külön köszönet illeti Máté Tamást, a találót, valamint a terepi kutatásban részt vevő és az azt segító intézményeket, munkatársakat: Janus Pannonius Múzeum (Pécs), Ferenczy Múzeumi Centrum (Szentendre), Kanizsai Dorottya Múzeum (Mohács), Hegedüs Gábor, Nagy Tibor - Detect Max Hungary Kft. 


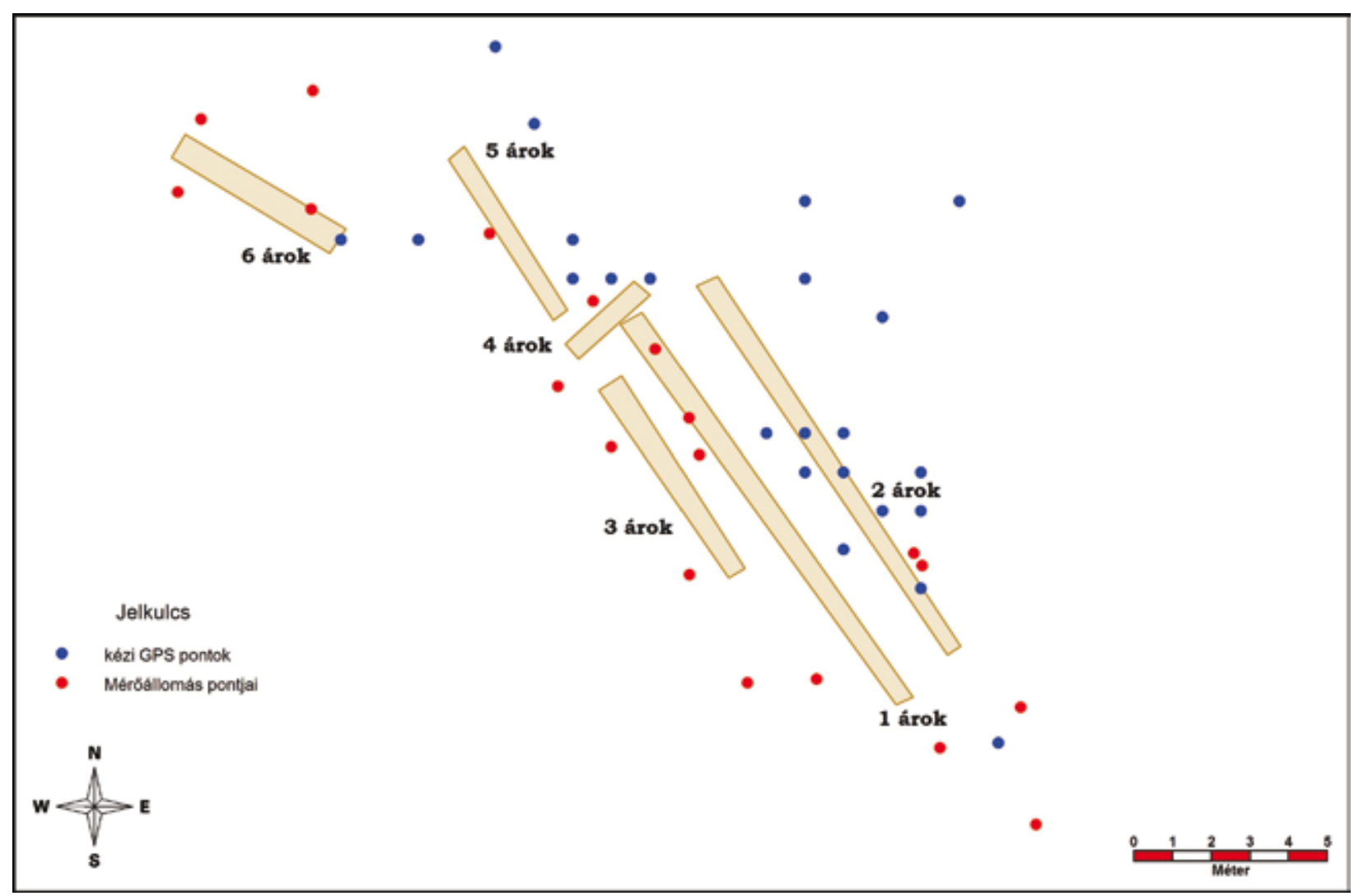

1. kép. Mohács-Sárhát. A mentőfeltárás helyszínrajza (készítette Simon Béla, JPM Régészeti Osztály)

Fig. 1. Mohács-Sárhát. Plan of the salvage excavation (by Béla Simon, JPM Department of Archaeology)

gálatával is járt. A terepbejárások során néhány késő középkori, fényes felületû, a korszakra jellemző szürke korsó töredéke került elő. A kerámiatöredékek a kincslelet tágabb környezetéból szórványosan kerültek elő. A múszeres leletfelderítések egyéb leletanyagban nem igazán bővelkedtek, bár a kincslelet szúkebb környezetében egy egyélú vaskést, egy kisméretú rézből készült, tölgyfalevél alakú ruhakapcsot, valamint egy rézből készült fülesgombot találtunk. A kerámia töredékekról és a fém leletanyagról összességében elmondható, hogy azok a 15-16. századra jellemzőek. Nagyobb felszíni leletkoncentráció hiányában azonban a lelőhely nem határozható meg településként. A csekélyszámú leletanyag és a kincslelet együttes értelmezése esetleg egy késő középkori, rövid ideig használt tanya helyére utalhat. ${ }^{4}$ A kincslelet helyétől légvonalban 4,5 km-re észak-északkeleti irányban található egy késő középkori faluhely, ahonnan roncsolásmentes múszeres leletfelderítéséből szórványosan előkerült 15-16. századi éremanyag (46 db) ismeretes. ${ }^{5}$

4 SZABó 1938, 11; KUBINYI 1986, 215.

5 Katona József Múzeum, Éremtár numizmatikai gyarapodási napló: 2018/111.
A késő középkori pénzek előkerülési koordinátáját GPS, illetve GNSS segítségével rögzítettük, majd az adatokat térképre vetettük. A pénzek egy kb. $20 \times 25$ m-es területen szóródtak szét, amit az intenzív mezőgazdasági múvelés eredményezett. Így a mentőfeltárás kapcsán összesen hat kutatóárkot húztunk azokra a területekre, melyektől további pénzek előkerülését vártuk (1. kép).

A kutatóárkokban egy ásónyom $(\mathrm{kb} .22 \mathrm{~cm})$ mélységben kutattunk, melynek során csak az 1. kutatóárok eredményezett újabb érméket ( $2 \mathrm{db}$ ). A mentőfeltárás eredményeként megállapítottuk, hogy a lelet 61 késő középkori dénárból, illetve egy ezüst fülesgombból állt. ${ }^{6}$ A kincsleletet a mai szántás mélységében (maximum $30 \mathrm{~cm}$ ) rejthették el, és a hozzá kapcsolódó egykori kontextus a kutatás idejére megsemmisült. ${ }^{7}$

6 A tanulmányban használt terminológia a numizmatika tudományában bevált, módszeresen használt, alkalmazása mégis sok esetben félreértésre ad okot. A továbbiakban a kincslelet kifejezést arra az esetre használjuk, amikor egy földben maradt/elrejtett leletegyüttes pénzeket és egyéb tárgyat/ tárgyakat is tartalmaz. A kincslelet a Janus Pannonius Múzeum Régészeti Osztályára került: Ltsz.: 2016.1.1-62.

7 Épített emlékre utaló felszíni leletanyag-sűrúsödést nem találtunk a lelőhelyen. A kincslelet szúkebb és tágabb környezetéből csekély számú, a 15-16. századra jellemző leletanyag került elő. 
A leletegyüttes mennyiségéből valószínúsíthetjük, hogy a pénzeket a gombbal együtt egy erszény tartalmazhatta.

\section{A késő középkori kincslelet történeti háttere}

Az előkerült 61 dénár kivétel nélkül II. Lajos uralkodása alatt került kibocsátásra, melyek a nova moneta, az 1521-1525-ig tartó pénzreform termékeként kerültek forgalomba. ${ }^{8}$ II. Lajos 1521. szeptember 1-jén új pénz veréséről rendelkezett. ${ }^{9}$ Az 1467-től 1521-ig kibocsátott ezüstpénzek finomságát felére redukálta, miszerint az addigi hivatalosan 8 lat finomságú ezüstpénzt 4 latosra módosította. ${ }^{10}$ Bár az új pénz feleannyi ezüstöt tartalmazott, árfolyamát mesterségesen fenntartották. A régi és új pénz átváltását 1521-ben 1:1hez határozták meg, amit 1523-ban már 1:1,1-hez számítottak. ${ }^{11}$ Ezt azonban alig egy évig sikerült tartani, az átváltási ár folyamatosan emelkedett, míg 1525-ben 1:2-ben határozták meg az árfolyamát. ${ }^{12}$ Huszár Lajos szerint ez a gyakorlatban 1:3, vagy inkább 1:4 arányban valósult meg, ${ }^{13}$ amit a nova moneták 1525 . évi bevonási árfolyama is megerősít (1:3). ${ }^{14} \mathrm{Ez}$ a pénztörténeti korszak a magyar pénzügy és gazdaság válságát idézte elő, egy olyan időszakban, amikor biztos anyagi alapok nélkül kellett szembenézni a magyar történelem egyik legválságosabb időszakával, melynek kezdetét az 1526. évi mohácsi vész jelentette. Igaz, 1525-ben az országgyúlés rendelkezett az értéktelennek minősített „ezüstpénzek” bevonásáról,15 de úgy tû́nik, hogy ez a döntés késve született meg. ${ }^{16}$ A forrásokból kitúnik, hogy hiába kezdték el 1525-ben ismét 8 lat finomságban verni az ezüstpénzeket, mivel a pénzforgalomban kialakult jó minőségú veretek hiányát még 1526-ban sem tudták pótolni. A korabeli forrásokból az is kiderül, hogy egyáltalán nem állt rendelkezésre nyersanyag, amit pénzzé tudtak volna verni, ezért az egyházi kegyszerek lefoglalását és beolvasztását rendelték el. Az így keletkezett ezüstöt igyekeztek nagyon gyorsan pénz-

8 E viszontagságokkal teli időszakot legutóbb Gyöngyössy Márton foglalta össze és egészítette ki számos új adattal. GYÖNGYÖSSY 2017, 607-644.

9 GYÖNGYÖSSY 2017, 622.

10 JESZENSZKY 1927-1928, 130.

11 DÁNYI-ZIMÁNYI 1989, 46.

12 SZABÓ 1909, 212; 1525. évi országgyúlés XX. cikkelye: CJH I, 832-833.

13 DÁNYI-ZIMÁNYi 1989, 46.

14 JESZENSZKY 1927-1928, 130.

15 SzABó 1909, 212; 1525. évi országgyúlés XX. cikkelye: CJH I, 832-833.

16 JESZENSZKY 1927-1928, 130. zé verni. ${ }^{17}$ Bár 1526-ban Bécsból 25 pénzverót és verőszerszámokat hozattak Budára, minden igyekezet ellenére sem sikerült elhárítani a gazdasági katasztrófát. ${ }^{18}$ A nova moneta idején kialakult monetáris válság 1526-ban csúcsosodott ki. Antonio Giovanni da Burgio pápai követ Jacopo Sadoleto pápai titkárnak Pozsonyból, 1526. március 27-én kelt levelében azt írta, hogy „,[a király] [t]ávozóban igen kért, hogy 100 gyalogost is szereljek fel neki, ezt már meg is tettem, de nem találok embert, aki elfogadná a zsoldot ebben a rossz pénzben, és jót nem lehet szerezni" ${ }^{19}$

II. Lajos király 10000 arany kölcsönt vett fel Szerencsés Imre alkincstartótól a hadikészületekre, ,[aki] parancsunknak engedelmeskedni és veszélyben forgó országunkon segíteni akarva úgy rendelkezett, hogy tízezer forintot jó érmében küldjenek a már említett kalocsai érsek úrnak és a naszádosoknak..."20

\section{Numizmatikai elemzés és értelmezés}

A kincsleletben levő dénárokat 1521. szeptember 1. és 1525. szeptember 1. között 4 lat finomságú ezüstből verték. Előlapjuk körirat nélküli, ábrázolásán negyedelt címerpajzs (1. mezó: magyar vágások, 2. mező: kettős kereszt, 3. mező: Dalmácia, 4. mező: cseh oroszlán) látható közepén szívpajzs a lengyel sassal. Hátlapjuk szintén körirat nélküli, ábrázolásán Nagyboldogasszony jobbján a gyermekkel látható. ${ }^{21}$

A kincslelet összetételét a numizmatikai statisztika módszerével elemeztük, mely során tüskediagram segítségével vizsgáltuk az időbeli összetételét a mennyiség függvényében (2. kép),

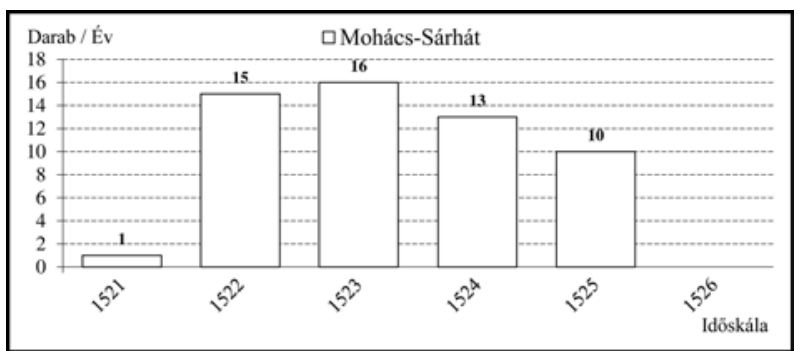

2. kép. Mohács-Sárhát. A kincslelet időbeli megoszlása

Fig. 2. Mohács-Sárhát. Chronological distribution of the hoard's coins

7 JESZENSZKY 1927-1928, 131.

18 JeSZENSZKY 1927-1928, 132.

19 Bartoniek Emma fordítása: B. SzABÓ 2006, 34

20 Buda, 1526. július 20. Bellus Ibolya fordítása: B. SzABÓ 2006, 73.

21 Soós 2014, 95. 


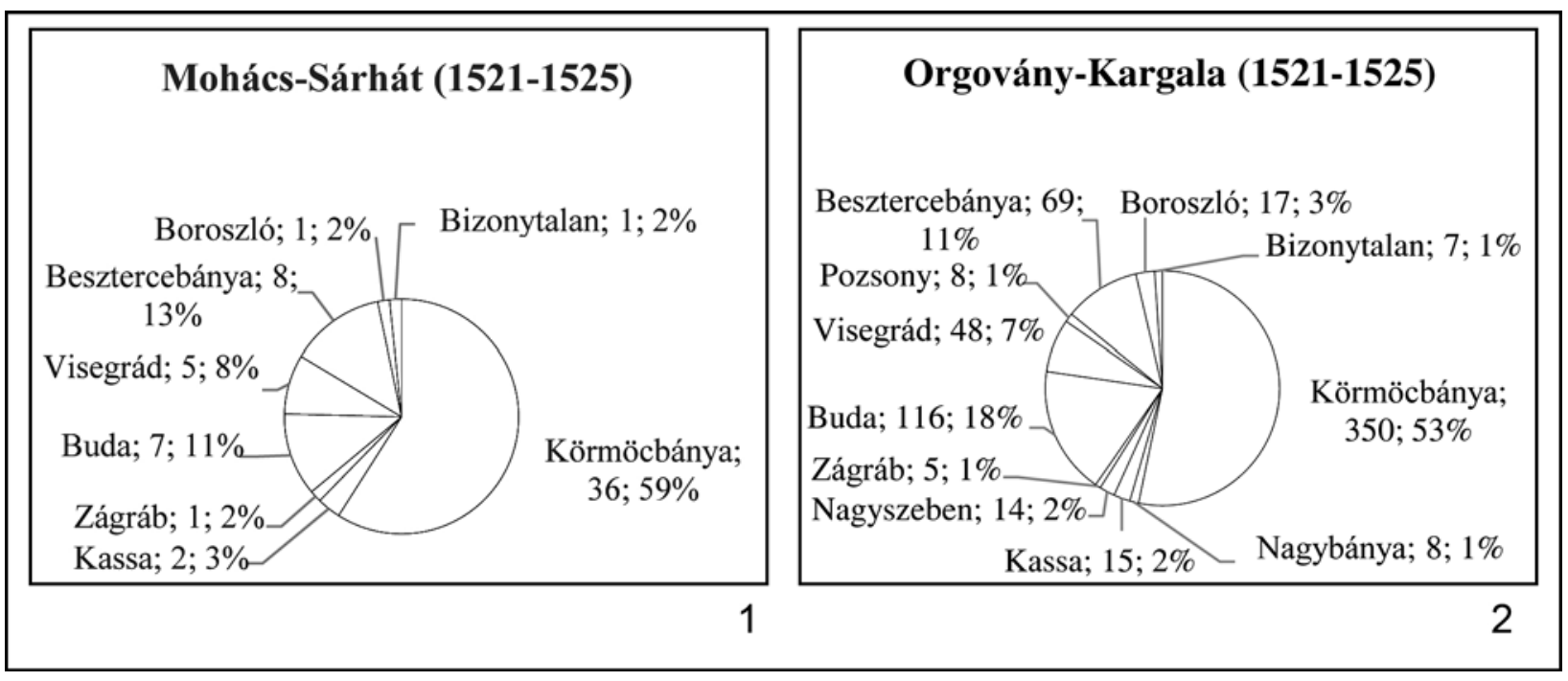

3. kép. Verdehely szerinti összetétel két nova monetából álló leletegyüttes megoszlásában. 1: Mohács-Sárhát; 2: OrgoványKargala

Fig. 3. Distribution of the coins according to mints in two nova moneta coin hoards. 1: Mohács-Sárhát; 2: Orgovány-Kargala

valamint a pénzek verdehely szerinti megoszlását is (3. kép 1).

A dénárok kibocsátási idejét alapul véve az 1521. évből összesen 1 dénárt tudtunk azonosítani. Az 1522. és az 1523. évi veretek a leginkább reprezentáltak, míg az 1524., 1525. esztendőben kibocsátott pénzek száma csökkenő tendenciát mutat (2. kép).

A kincslelet verdehely szerinti összetételében (3. kép 1) a körmöci kamara veretei dominálnak, azonban jelentős a budai, a besztercebányai és a visegrádi verdéból származó pénzek mennyisége is.22 Elenyésző számban megtalálhatók a boroszlói, a zágrábi és a kassai pénzverőhely dénárjai. A körmöci kamara aprópénzverésben tapasztalható domináns szerepe már II. Ulászló (1490-1516) uralkodásának idején megmutatkozott, és II. Lajos (1516-1526) pénzkibocsátására is jellemző maradt. ${ }^{23}$

\section{Párhuzamok}

A párhuzamok keresésénél elsődlegesen két tényezőt vettünk figyelembe: 1 . köthető-e a kincslelet elrejtése és földben maradása történeti kontextushoz; 2. létezik-e olyan leletegyüttes, melynek összetétele hasonló, és történetileg, valamint földrajzilag is kapcsolatba hozható a MohácsSárháton előkerült kincslelettel.

\footnotetext{
22 Az L-S (Mzz. 258-11) verdejegy besztercebányai azonosításával a közelmúltban a kutatás eredményesen foglalkozott: GYÖNGYÖSSY 2017, 628.
}

23 NAGY 2015, 288.
1. A kincsleletben levő legkésőbbi, 1525. évi veretek alapján azok elrejtésének és földben maradásának közvetett okaként a mohácsi vész után bekövetkezett események említhetők, ami mögött a leletegyüttes tulajdonosának a halálát kell feltételeznünk (mivel pénzéért nem tudott visszatérni).

2. A mohácsin kívül jelenleg csupán egy olyan éremlelet ismeretes, mely kivétel nélkül nova monetából áll. Ez a Bács-Kiskun megyei Orgovány-Kargalán került elő. ${ }^{24}$ Összesen öt olyan leletegyüttest ismerünk (Bakonyoszlop, ${ }^{25}$ Érsekcsanád-Szentgyörgy, ${ }^{26}$ Mohács-Sárhát, Orgovány-Kargala, ${ }^{27}$ Szederkény ${ }^{28}$ ), melyekben

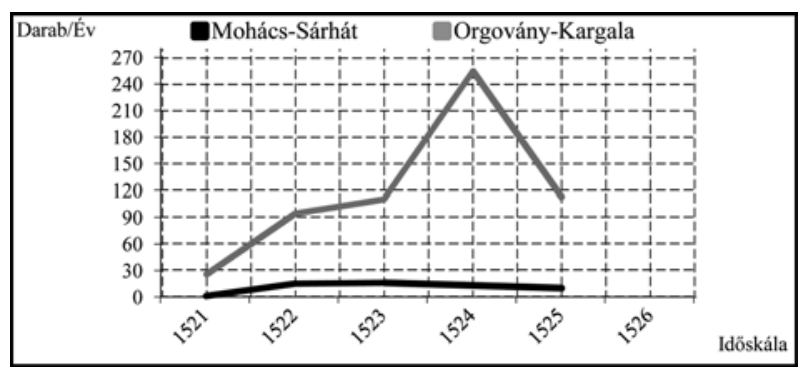

4. kép. Mohács-Sárhát és Orgovány-Kargala érmeinek száma és az érmék kibocsájtásának éve

Fig. 4. Number of coins and the year of issue of the coins in the Mohács-Sárhát and Orgovány-Kargala hoards

24 NAGY 1986, 181.

25 KÁLNOKI-GYÖNGYÖSSY 2015, 141, 222-223.

26 A közlését a közeljövőben Csuvár-Andrási Rékával (Türr István Múzeum) közösen tervezzük.

27 NaGY 1986, 181.

$28 \mathrm{Az}$ éremlelet ismeretlen helyen lappang. Fejes 1928, 38. PARÁdi 1963, 210, 212. NAGY 2016, 37-38. 
a legkésőbbi veret 1525-ben készült, és a földben maradásuk a törökök 1526. évi pusztításaival hozható összefüggésbe.

Bár az Orgovány-Kargalán előkerült éremlelet összetételében lévő pénztípusok azonosak a Mohács-Sárháton találttal, időbeli megoszlásuk mégis eltérően alakul, ami vélhetően a mennyiségből adódó különbségből fakadhat. Hasonlóan kis mennyiségú pénzt tartalmazó leletegyüttest nem ismerünk, és mivel az orgoványi éremlelet darabszáma meglehetősen eltér a sárhátitól, így további elemzésbe nem kívánunk bocsátkozni (4. kép). Verdehely szerinti összetételük viszont összehasonlításra érdemes (3. kép 1-2). A két diagramból megállapítható a körmöcbányai verde domináns szerepe, míg jelentós pénzkibocsátási tevékenységgel bírt a budai és a szomolnoki verde is.

\section{Összegzés}

A Mohács-Sárháton talált kincslelet mentő feltárása az elrejtés szúkebb környezetének jellegére vonatkozóan nem hozott eredményeket. A kincslelet tágabb környezetének rekonstruálását a szegényes és csekély számú felszíni leletanyag segítheti, amely egy késő középkori, rövid ideig álló paraszttanyára utalhat. E kincslelet a mohácsi vész idejéből származók közül a legkisebb és a legértéktelenebb, mégis figyelemre méltó. Összetételében nem találunk mást, mint az 1521től 1526-ig tartó válságos időszakra jellemző, értékét vesztett nova moneta-dénárt. A kincslelet korabeli értéke számítási forintban megadva nagyjából 0,33 lehetett. Ebből az összegből az egykori tulajdonos csupán a napi kiadásait tudta fedezni. Viszonyításként felsorolunk néhány árat, melyek nova monetában számolva értendők: 1524-ben 1 mérő (átlagos értéke: $40 \mathrm{~kg}$ ) zabot 20 dénárért lehetett venni, ${ }^{29}$ egy kenyér pedig 1523-ban 2 dénárba került. ${ }^{30} \mathrm{~A}$ mohács-sárháti kincsleletért tehát kicsit több mint 3 méró zabot lehetett volna 1525-ben vásárolni. A kincslelet a legkésőbbi veret alapján 1525-ben záródik, elrejtését és földben maradását nagy valószínúséggel az 1526. évi eseményekhez köthetjük.

\section{KATALÓGUS}

A katalógusban használt általános rövidítések feloldása:

\section{Múzeum}

JPM: Janus Pannonius Múzeum, Pécs

\section{Verdehelyek}

A.: Agram (ma: Zágráb, HR)

B.: Buda (ma: Budapest, HU)

B.B.: Besztercebánya (ma: Banská Bystrica, SK)

K.: Kassa (ma: Košice, SK)

K.B.: Körmöcbánya (ma: Kremnica, SK)

V.: Visegrád (HU)

W.: Boroszló (ma: Wrocław, PL)

$$
\text { Uralkodó }
$$

L: II. Lajos (1516-1526)

D/É: dénár/ép

Egyéb

D/S: dénár/sérült

E: előlap

H: hátlap

K.N.: körirat nélkül

\section{Elő- és hátlapi ábrázolások}

E.: Negyedelt címerpajzs - magyar vágások kettőskereszttel - leopárd fejekkel (Dalmácia címere) oroszlánnal (Csehország címere), szívpajzsban: sas (Lengyelország címere)

H.: Koronázott Madonna (Nagyboldogasszony) bő ruhában, jobbján gyermekkel

\section{Használt referenciák feloldása}

Mzz.: Pohl 1982.

\section{Oszlopok feloldása}

1. Számozás

2. Leltári szám (JPM)

3. Kibocsátó

4. Címlet/állapot

5. Verdejegy/verdehely

6. Kibocsátás ideje

7. Elölapi körirat

8. Hátlapi körirat

9. Súly (gramm)

10. Átmérő (milliméter)

11. Referenciaszám 


\section{A kincslelet összetétele}

\begin{tabular}{|c|c|c|c|c|c|c|c|c|c|c|}
\hline 1. & 2. & 3. & 4. & 5. & 6. & 7. & 8. & 9. & 10. & 11. \\
\hline 1. & 2016.1.1 & $\mathrm{L}$ & $\mathrm{D} / \mathrm{S}$ & B-W (W.) & 1525 & K.N. & K.N. & 0,38 & 15,69 & Mzz. 258-18 \\
\hline 2. & 2016.1 .2 & $\mathrm{~L}$ & $\mathrm{D} / \mathrm{E}$ & L-K (K.B.) & 1523 & K.N. & K.N. & 0,46 & 15,51 & Mzz. 258-2 \\
\hline 3. & 2016.1 .3 & $\mathrm{~L}$ & $\mathrm{D} / \mathrm{S}$ & L-K (K.B.) & 1523 & K.N. & K.N. & 0,31 & 13,92 & Mzz. 258-2 \\
\hline 4. & 2016.1.4 & $\mathrm{L}$ & $\mathrm{D} / \mathrm{S}$ & L-S (B.B.) & $\begin{array}{c}1523- \\
1525\end{array}$ & K.N. & K.N. & 0,24 & 15,02 & Mzz. 258-11 \\
\hline 5. & 2016.1.5 & $\mathrm{L}$ & $\mathrm{D} / \mathrm{S}$ & L-K (K.B.) & 1525 & K.N. & K.N. & 0,31 & 14,32 & Mzz. 258-2 \\
\hline 6. & 2016.1.6 & $\mathrm{L}$ & $\mathrm{D} / \mathrm{S}$ & L-K (K.B.) & 1522 & K.N. & K.N. & 0,20 & 14,41 & Mzz. 258-2 \\
\hline 7. & 2016.1 .7 & $\mathrm{~L}$ & $\mathrm{D} / \mathrm{S}$ & L-K (K.B.) & 1522 & K.N. & K.N. & 0,25 & 14,66 & Mzz. 258-2 \\
\hline 8. & 2016.1 .8 & $\mathrm{~L}$ & $\mathrm{D} / \mathrm{S}$ & L-K (K.B.) & 1522 & K.N. & K.N. & 0,35 & 14,34 & Mzz. 258-2 \\
\hline 9. & 2016.1 .9 & $\mathrm{~L}$ & D/É & L-K (K.B.) & 1523 & K.N. & K.N. & 0,57 & 15,95 & Mzz. 258-2 \\
\hline 10. & 2016.1.10 & L & $\mathrm{D} / \mathrm{S}$ & L-K (K.B.) & $\begin{array}{c}1521- \\
1525 \\
\end{array}$ & K.N. & K.N. & 0,41 & 15,41 & Mzz. 258-2 \\
\hline 11. & 2016.1.11 & $\mathrm{L}$ & D/É & L-B (B.) & 1522 & K.N. & K.N. & 0,42 & 15,28 & Mzz. 258-1 \\
\hline 12. & 2016.1.12 & $\mathrm{L}$ & D/É & L-B (B.) & 1524 & K.N. & K.N. & 0,37 & 15,89 & Mzz. 258-1 \\
\hline 13. & 2016.1.13 & $\mathrm{L}$ & $\mathrm{D} / \mathrm{E}$ & L-S (B.B.) & 1523 & K.N. & K.N. & 0,41 & 15,32 & Mzz. 258-11 \\
\hline 14. & 2016.1 .14 & $\mathrm{~L}$ & D/É & L-B (B.) & 1522 & K.N. & K.N. & 0,43 & 14,70 & Mzz. 258-1 \\
\hline 15. & 2016.1.15 & $\mathrm{L}$ & D/É & L-B (B.) & 1523 & K.N. & K.N. & 0,40 & 16,08 & Mzz. 258-1 \\
\hline 16. & 2016.1.16 & $\mathrm{L}$ & $\mathrm{D} / \mathrm{E}$ & L-K (K.B.) & 1524 & K.N. & K.N. & 0,49 & 14,39 & Mzz. 258-2 \\
\hline 17. & 2016.1.17 & $\mathrm{L}$ & D/É & L-K (K.B.) & 1523 & K.N. & K.N. & 0,55 & 15,31 & Mzz. 258-2 \\
\hline 18. & 2016.1.18 & L & $\mathrm{D} / \mathrm{S}$ & L-K (K.B.) & $\begin{array}{c}1521- \\
1525 \\
\end{array}$ & K.N. & K.N. & 0,16 & 14,25 & Mzz. 258-2 \\
\hline 19. & 2016.1.19 & $\mathrm{L}$ & D/É & L-K (K.B.) & 1523 & K.N. & K.N. & 0,51 & 14,74 & Mzz. 258-2 \\
\hline 20. & 2016.1.20 & $\mathrm{L}$ & $\mathrm{D} / \mathrm{S}$ & L-B (B.) & 1524 & K.N. & K.N. & 0,45 & 15,88 & Mzz. 258-1 \\
\hline 21. & 2016.1.21 & $\mathrm{L}$ & $\mathrm{D} / \mathrm{S}$ & L-K (K.B.) & 1522 & K.N. & K.N. & 0,31 & 12,22 & Mzz. 258-2 \\
\hline 22. & 2016.1.22 & $\mathrm{L}$ & $\mathrm{D} / \mathrm{S}$ & L-K (K.B.) & 1522 & K.N. & K.N. & 0,31 & 16,60 & Mzz. 258-2 \\
\hline 23. & 2016.1.23 & $\mathrm{L}$ & $\mathrm{D} / \mathrm{S}$ & L-C (K.) & 1522 & K.N. & K.N. & 0,48 & 15,69 & Mzz. 258-3 \\
\hline 24. & 2016.1.24 & $\mathrm{L}$ & $\mathrm{D} / \mathrm{S}$ & L-S (B.B.) & 1524 & K.N. & K.N. & 0,31 & 14,95 & Mzz. 258-11 \\
\hline 25. & 2016.1.25 & L & D/É & L-K (K.B.) & 1523 & K.N. & K.N. & 0,43 & 16,10 & Mzz. 258-2 \\
\hline 26. & 2016.1.26 & $\mathrm{L}$ & D/É & L-K (K.B.) & 1523 & K.N. & K.N. & 0,45 & 15,55 & Mzz. 258-2 \\
\hline 27. & 2016.1.27 & $\mathrm{L}$ & D/É & L-K (K.B.) & 1523 & K.N. & K.N. & 0,26 & 14,16 & Mzz. 258-2 \\
\hline 28. & 2016.1.28 & $\mathrm{L}$ & D/É & L-K (K.B.) & 1524 & K.N. & K.N. & 0,49 & 15,41 & Mzz. 258-2 \\
\hline 29. & 2016.1.29 & $\mathrm{L}$ & $\mathrm{D} / \mathrm{S}$ & L-K (K.B.) & 1522 & K.N. & K.N. & 0,32 & 15,46 & Mzz. 258-2 \\
\hline 30. & 2016.1.30 & $\mathrm{L}$ & $\mathrm{D} / \mathrm{S}$ & L-K (K.B.) & 1522 & K.N. & K.N. & 0,37 & 14,61 & Mzz. 258-2 \\
\hline 31. & 2016.1.31 & $\mathrm{L}$ & $\mathrm{D} / \mathrm{E}$ & L-S (B.B.) & 1525 & K.N. & K.N. & 0,46 & 15,83 & Mzz. 258-11 \\
\hline 32. & 2016.1.32 & $\mathrm{L}$ & D/É & L-B (B.) & 1524 & K.N. & K.N. & 0,40 & 15,24 & Mzz. 258-1 \\
\hline 33. & 2016.1.33 & $\mathrm{L}$ & D/É & L-K (K.B.) & 1525 & K.N. & K.N. & 0,55 & 14,79 & Mzz. 258-2 \\
\hline 34. & 2016.1.34 & $\mathrm{L}$ & D/É & L-3 (A.) & 1524 & K.N. & K.N. & 0,73 & 15,33 & Mzz. 258-10 \\
\hline 35. & 2016.1.35 & $\mathrm{L}$ & D/É & L-K (K.B.) & 1523 & K.N. & K.N. & 0,60 & 16,14 & Mzz. 258-2 \\
\hline 36. & 2016.1 .36 & $\mathrm{~L}$ & $\mathrm{D} / \mathrm{E}$ & L-V (V.) & 1524 & K.N. & K.N. & 0,58 & 15,36 & Mzz. 258-8 \\
\hline 37. & 2016.1.37 & $\mathrm{L}$ & $\mathrm{D} / \mathrm{S}$ & L-K (K.B.) & 1524 & K.N. & K.N. & 0,55 & 14,18 & Mzz. 258-2 \\
\hline 38. & 2016.1.38 & $\mathrm{L}$ & $\mathrm{D} / \mathrm{E}$ & L-K (K.B.) & 1522 & K.N. & K.N. & 0,54 & 14,83 & Mzz. 258-2 \\
\hline 39. & 2016.1.39 & $\mathrm{L}$ & D/É & L-K (K.B.) & 1522 & K.N. & K.N. & 0,56 & 15,82 & Mzz. 258-2 \\
\hline 40. & 2016.1.40 & $\mathrm{L}$ & $\mathrm{D} / \mathrm{S}$ & L-K (K.B.) & 1522 & K.N. & K.N. & 0,46 & 16,29 & Mzz. 258-2 \\
\hline 41. & 2016.1.41 & $\mathrm{L}$ & $\mathrm{D} / \mathrm{E}$ & L-K (K.B.) & 1522 & K.N. & K.N. & 0,47 & 15,98 & Mzz. 258-2 \\
\hline 42. & 2016.1.42 & $\mathrm{L}$ & $\mathrm{D} / \mathrm{S}$ & $\mathrm{L}-[$ & 1524 & K.N. & K.N. & 0,40 & 15,66 & Mzz. 258 \\
\hline
\end{tabular}


(táblázat folyt.)

\begin{tabular}{|c|c|c|c|c|c|c|c|c|c|c|}
\hline 1. & 2. & 3. & 4. & 5. & 6. & 7. & 8. & 9. & 10. & 11. \\
\hline 43. & 2016.1.43 & L & $\mathrm{D} / \mathrm{S}$ & L-K (K.B.) & 1523 & K.N. & K.N. & 0,35 & 15,44 & Mzz. 258-2 \\
\hline 44. & 2016.1.44 & L & D/É & L-B (B.) & 1522 & K.N. & K.N. & 0,57 & 15,59 & Mzz. 258-1 \\
\hline 45. & 2016.1.45 & $\mathrm{L}$ & $\mathrm{D} / \mathrm{S}$ & L-S (B.B.) & 1525 & K.N. & K.N. & 0,41 & 14,43 & Mzz. 258-11 \\
\hline 46. & 2016.1.46 & $\mathrm{L}$ & D/É & L-V (V.) & 1524 & K.N. & K.N. & 0,36 & 15,85 & Mzz. 258-8 \\
\hline 47. & 2016.1.47 & $\mathrm{L}$ & $\mathrm{D} / \mathrm{S}$ & L-C (K.) & 1524 & K.N. & K.N. & 0,33 & 16,87 & Mzz. 258-3 \\
\hline 48. & 2016.1.48 & L & $\mathrm{D} / \mathrm{S}$ & L-K (K.B.) & 1525 & K.N. & K.N. & 0,30 & 14,76 & Mzz. 258-2 \\
\hline 49. & 2016.1.49 & $\mathrm{L}$ & D/É & L-V (V.) & 1525 & K.N. & K.N. & 0,50 & 15,19 & Mzz. 258-8 \\
\hline 50. & 2016.1.50 & $\mathrm{L}$ & $\mathrm{D} / \mathrm{E}$ & L-K (K.B.) & 1523 & K.N. & K.N. & 0,59 & 15,40 & Mzz. 258-2 \\
\hline 51. & 2016.1.51 & $\mathrm{L}$ & $\mathrm{D} / \mathrm{S}$ & L-K (K.B.) & 1524 & K.N. & K.N. & 0,37 & 15,33 & Mzz. 258-2 \\
\hline 52. & 2016.1.52 & $\mathrm{L}$ & $\mathrm{D} / \mathrm{E}$ & L-K (K.B.) & 1523 & K.N. & K.N. & 0,56 & 15,43 & Mzz. 258-2 \\
\hline 53. & 2016.1.53 & $\mathrm{L}$ & D/É & L-S (B.B.) & 1523 & K.N. & K.N. & 0,47 & 15,22 & Mzz. 258-11 \\
\hline 54. & 2016.1.54 & $\mathrm{L}$ & D/É & L-K (K.B.) & 1521 & K.N. & K.N. & 0,47 & 15,61 & Mzz. 258-2 \\
\hline 55. & 2016.1 .55 & $\mathrm{~L}$ & D/É & L-K (K.B.) & 1523 & K.N. & K.N. & 0,52 & 15,72 & Mzz. 258-2 \\
\hline 56. & 2016.1.56 & L & $\mathrm{D} / \mathrm{S}$ & L-K (K.B.) & $\begin{array}{c}1521- \\
1525 \\
\end{array}$ & K.N. & K.N. & 0,41 & 15,85 & Mzz. 258-2 \\
\hline 57. & 2016.1.57 & $\mathrm{L}$ & $\mathrm{D} / \mathrm{S}$ & L-S (B.B.) & 1524 & K.N. & K.N. & 0,37 & 15,14 & Mzz. 258-11 \\
\hline 58. & 2016.1 .58 & $\mathrm{~L}$ & D/É & L-V (V.) & 1525 & K.N. & K.N. & 0,55 & 15,10 & Mzz. 258-8 \\
\hline 59. & 2016.1.59 & L & $\mathrm{D} / \mathrm{S}$ & L-S (B.B.) & $\begin{array}{c}1523- \\
1525\end{array}$ & K.N. & K.N. & 0,34 & 15,16 & Mzz. 258-11 \\
\hline 60. & 2016.1 .60 & L & $\mathrm{D} / \mathrm{S}$ & L-K (K.B.) & $\begin{array}{c}1521- \\
1525\end{array}$ & K.N. & K.N. & 0,28 & 14,30 & Mzz. 258-2 \\
\hline 61. & 2016.1.61 & L & $\mathrm{D} / \mathrm{S}$ & L-V (V.) & 1525 & K.N. & K.N. & 0,36 & 14,72 & Mzz. 258-8 \\
\hline 62. & 2016.1.62 & $\begin{array}{l}\text { füles- } \\
\text { gomb } \\
\text { (ezüst) }\end{array}$ & & & $\begin{array}{c}15 . \\
\text { század } \\
\text { második } \\
\text { fele - } \\
1526 \\
\text { előtt }\end{array}$ & & & & & \\
\hline
\end{tabular}

\section{IRODALOM}

B. SZABÓ JÁNOS (szerk.)

2006 Mohács. Budapest.

1899 Corpus Juris Hungarici. I. Magyar Törvénytár. I. 1000-1526. évi törvényczikkek. Az 1000-1301 közt alkotott törvényeket fordította és jegyzetekkel ellátta Nagy Gyula. Az 1301-1526 közt alkotott törvényeket fordították és jegyzetekkel ellátták Kolosvári Sándor és Óvári Kelemen. Az 1000-1526. évi törvényeket magyarázatokkal és utalásokkal kíséri Márkus Dezső. Budapest.

DÁNYI DEZSÓ-ZiMÁNYI VeRA

1989 Soproni árak és bérek a középkortól 1750-ig. Budapest.

FEJES GYÖRGY

1928 A múzeum közleményei. Pécs-Baranyamegyei Múzeumi Értesítő 10, 37-43.

GYÖNGYÖSSY MÁRTON

2017 II. Lajos legendás alkincstartója, Szerencsés Imre és a moneta nova. Századok 151/3, 607-644.

JESZENSZKY GÉZA

1927-1928 II. Lajos denárai. Numizmatikai Közlöny (Budapest) 26-27, 127-143.

KÁLNOKI-GYÖNGYÖSSY MÁRTON

2015 Pénzverés és pénzforgalom Nyugat-Magyarországon (1387-1608). Akadémiai doktori értekezés. Budapest.

KUBINYI ANDRÁS

1986 A nagybirtok és jobbágyai a középkor végén az 1478-as Garai-Szécsi birtokfelosztás alapján. A Veszprém Megyei Múzeumok Közleményei (Veszprém) 18, 197-216. 


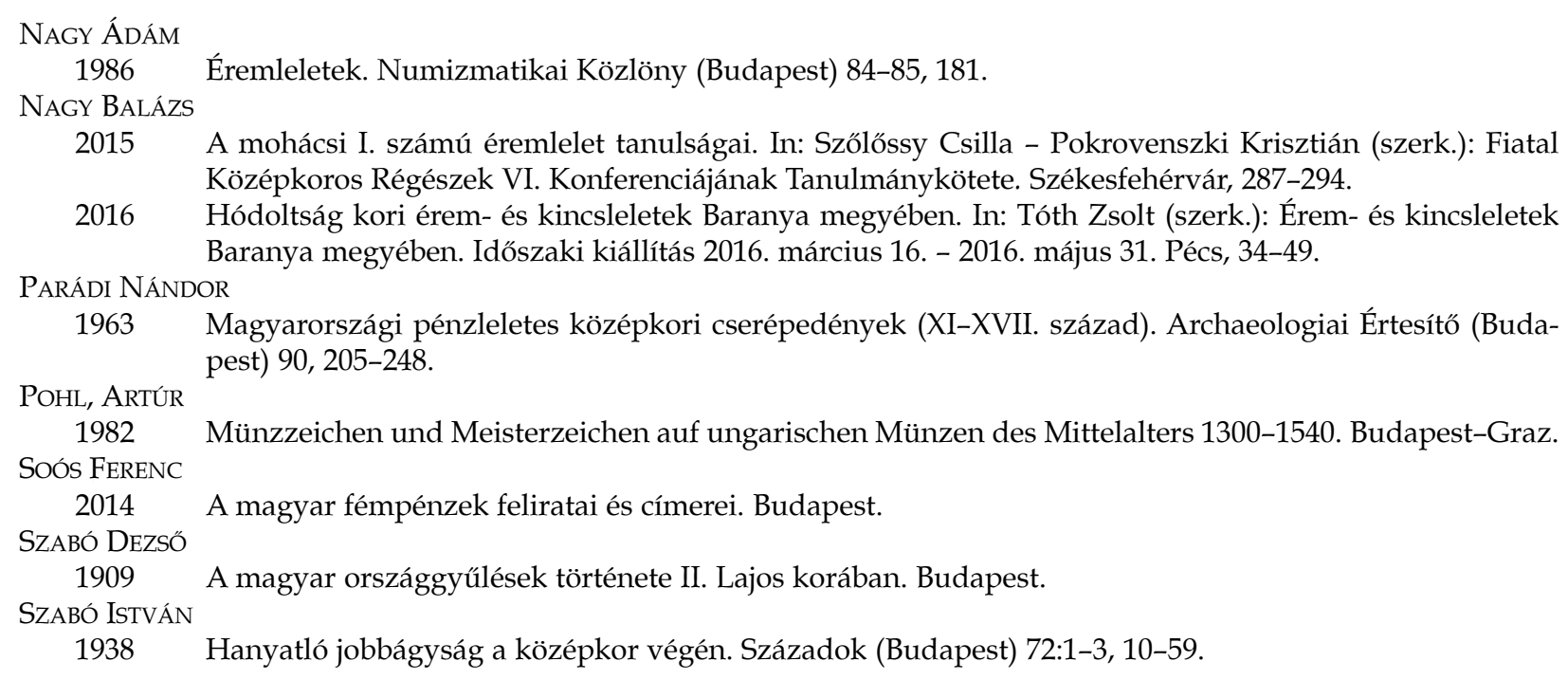

\section{A LATE MEDIEVAL HOARD FROM MOHÁCS-SÁRHÁT}

\section{BALÁZS NAGY - MÁRTON GYÖNGYÖSSY - OliVÉR GÁBOR}

In Spring 2016, a volunteer metal detectorist of the Janus Pannonius Museum of Pécs discovered several late medieval denarii. We repeatedly went over the area with a metal detector and then conducted a salvage excavation in the area of the findspot, as a result of which we recovered sixty-one nova moneta denarii and a silver looped button. The excavation did not yield any results regarding the archaeological context of the assemblage. The scanty late medieval finds brought to light from the broader area suggest that the hoard can be associated with a farmstead-like building. The hoard contained issues inscribed with dates that had been minted between 1521 and 1525, suggesting that the concealment of the hoard can be associated with the events of 1526 , specifically with the withdrawal of the Turkish forces in October 1526. The value of the hoard around 1525 is illustrated by its purchasing power: its value was the equivalent of $120 \mathrm{~kg}$ of rye or at least $20 \mathrm{~kg}$ of bread.

A cikk a Creative Commons Attribution 4.0 International License (https://creativecommons.org/licenses/by/4.0) feltételei szerint publikált Open Access közlemény, melynek szellemében a cikk bármilyen médiumban szabadon felhasználható, megosztható és újraközölhető, feltéve, hogy az eredeti szerző és a közlés helye, illetve a CC License linkje és az esetlegesen végrehajtott módosítások feltüntetésre kerülnek. (SID_1) 